ISSN 1392-3196 / e-ISSN 2335-8947

Zemdirbyste-Agriculture, vol. 100, No. 3 (2013), p. 317-324

DOI 10.13080/z-a.2013.100.041

\title{
Comparison of spring barley (Hordeum vulgare L.) screening methods for Fusarium head blight resistance breeding
}

\author{
Guna ŪSELE, Indra BEINAROVIČA, Ieva MEŽAKA, Linda LEGZDIN̦A \\ State Priekuli Plant Breeding Institute \\ Zinatnes 1A, Priekuli, Latvia \\ E-mail: guna.usele@gmail.com
}

\begin{abstract}
Fusarium head blight (FHB) is a widespread disease of cereals, including barley (Hordeum vulgare L.), that causes substantial grain yield losses and grain quality deterioration. Resistant varieties provide the greatest potential for reducing FHB. In the present study, we adapted two methods for screening FHB severity using Fusarium culmorum. We used a cut-spike method and a spray inoculation method in the field conditions for screening different spring barley genotypes of Latvian and foreign origin. Screening with the cut-spike method was done for 126 different genotypes in 2008 and in 2009 and for 180 genotypes in 2010. In the years 2011 and 2012, the field inoculation method was used to screen 207 and 164 genotypes, respectively; part of material was tested simultaneously by both methods. A significant effect of genotype was found for both cut-spike and field inoculation methods $(p<0.001)$; field inoculation method showed a greater proportion of genotype effect and a higher heritability. Using area under the disease progress curve (AUDPC) and score obtained at 26 days after inoculation were equally effective. Correlations between results obtained by both methods in different years were not significant, though, the data of the same year correlated significantly $(r=0.36-0.47, p<0.05)$. Results suggest that differences between breeding material can be assessed by both methods; however, the information obtained was contradictory for a number of genotypes. Considering the results and the fact that field inoculation method can more likely provide results of equal value to those in natural conditions in respect to identification of resistant and susceptible genotypes, field inoculation method was recognized as preferable for the assessment of spring barley breeding material. Significant correlation $(r=0.71$, $p<0.05$ ) between visual estimate of disease severity and mycotoxin deoxynivalenol (DON) concentration in grain was found in 2011, but in the environmental conditions of 2012 formation of DON was inhibited.
\end{abstract}

Key words: cut-spike method, DON, field inoculation method, Fusarium culmorum, genotype effect.

\section{Introduction}

Fusarium head blight (FHB) is a widespread disease of cereals, including wheat (Triticum spp.) and barley (Hordeum vulgare L.), which infects spikes and reduces grain yield and quality. In addition, FHB is a significant threat to food and feed chains, because certain Fusarium species may produce mycotoxins in the infected grain. The presence of mycotoxins in grain may cause technological problems of malt production (toxins reduce enzyme synthesis), interfere with the quality of bread baking and health problems in humans and animals (Placinta et al., 1999).

Seventeen Fusarium species are reported to cause FHB; the most widespread ones are: F. graminearum, F. culmorum, $F$. avenaceum and $F$. poae, which can produce a range of mycotoxins (Parry et al., 1995; Brennan et al., 2005; Audenaert et al., 2009). In Europe, FHB is caused by at least four species of Fusarium including $F$. graminearum and F. culmorum (Diamond, Cooke, 1999; Ioos et al., 2004; Browne, Cooke, 2005). Fusarium graminearum particularly grows in warm regions whereas $F$. culmorum, $F$. poae, $F$. avenaceum and Microdochium nivale tend to dominate in cooler regions (Parry et al., 1995; Doohan et al., 2003; Waalwijk et al., 2003; Xu et al., 2005).

The most common mycotoxins caused by fungi of the genus Fusarium are deoxynivalenol (DON) and zearalenone (ZEN). The amount of mycotoxins in grain is mostly affected by climatic conditions and genotype (Placinta et al., 1999). The ability to produce toxins and toxin-producing activity vary not only among the Fusarium species, but also between different strains of the same species. European Commission Regulation (EC) No. 1881/2006 (Anonymous, 2006), which regulates certain contaminants in foodstuffs, determines maximum allowed DON content norm in unprocessed grains $1250 \mathrm{mg} \mathrm{kg}^{-1}$. Some studies have demonstrated a high and positive correlation between disease severity in the field and the concentration of DON in grain (Zhu et al., 1999; Buerstmayr et al., 2004). It allows a breeder to select lines with lover FHB severity and at the same time with low mycotoxin accumulation in grain. The risk of FHB infection is higher in the time around flowering (Buerstmayr et al., 2004). Modelling of field data suggests that FHB development is greatly affected by the temperature and free moisture (Xu et al., 2005). Although the higher infection rate has been observed in hot and humid weather, the most favourable conditions for production of mycotoxins are damp and chilly weather.

Cultivation of genetically resistant cultivars is the most cost-effective and environmentally-friendly method to control the disease also to control mycotoxin contamination of grain. Genetic variation for resistance to FHB is well documented in wheat and its relatives (Snijders, 1990; Mesterhazy, 1995). The genetics and 
expression of resistance to FHB in barley is complex. Difficulties to accurately measure Fusarium resistance are reported (Yoshida et al., 2005) and only few studies address FHB resistance in barley (Mesterhazy et al., 1999; Buerstmayr et al., 2004; Brennan et al., 2005; Xu et al., 2005). Within the lines from the genebank and the current European spring barleys, a wide range of variation for FHB resistance is evident (Buerstmayr et al., 2004). Limited and contradictory information on heritability for FHB resistance is available. In wheat broad sense heritability for various genetic materials, environments and testing methods is reported in range from 5\% to 93\% (Snijders, 1990; Singh et al., 1995). For FHB resistance in various spring barley genotypes Buerstmayr et al. (2004) estimated heritability of $81-84 \%$ and Takeda (2004) reported $60 \%$.

Evaluation of barley and wheat for FHB resistance is generally performed with artificial inoculation. Although greenhouse screening is possible, most screening is done in the field conditions because of the low correlation between greenhouse and field data (Rudd et al., 2001). On the other hand, Mesfin et al. (2003) stated that greenhouse evaluations ensure control of heading date and environment after inoculation and are thus useful for selecting resistant genotypes. Benefit of greenhouse screening is a possibility to control temperature and humidity, as the effect of both those factors during and after inoculation plays a crucial role in the infection process. Varying atmospheric conditions may lead to a significant bias in the resistance evaluations and to sometimes large genotype $\times$ environment interactions and poor correlations between experiments (Mesfin et al., 2003), especially when the genotypes under investigation differ significantly in flowering date (Buerstmayr et al., 2004). One of methods used for inoculation in controlled environments is cut-spike method, which enables definite inoculation at the time of flowering and it is possible to test simultaneously plants with different flowering time (Takeda, 2004). Statistically significant correlation between cut-spike and other method in controlled conditions - pot-plant method - has been reported (Han, Kim, 2005). Screening methods differ not only by the environment where testing is performed, but also by different techniques of inoculation - spray inoculation, injection method, and canary seed method (placing single infested canary seed in a single spikelet in the middle of the spike) can be used in testing for resistance to FHB (Grewal et al., 2004). The statistically significant interaction between barley genotypes and Fusarium strain used was not found (Takeda, 2004).

The main aim of the study was to evaluate the results obtained by cut-spike method and spray inoculation method applied in field conditions for FHB severity screening, compare both methods and identify the most appropriate method for breeding purposes in low-budget breeding program, as well as to select the most resistant genotypes for using as parents in breeding.

\section{Materials and methods}

Plant material. Three groups of genotypes were used in the study. 1. Collection of diverse varieties and breeding lines, including some with previously known resistance or susceptibility (hereinafter referred to as "collection"); the number and the composition of the genotypes varied among the years (Table 1). In 2008 and 2009, collection consisted of 104 accessions of Latvian origin ( 80 breeding lines and 34 varieties) and 22 foreign cultivars. In 2010, there were 39 accessions of Latvian origin ( 9 varieties and 30 breeding lines) and 7 foreign varieties. During 2011-2012 33 genotypes were of Latvian origin ( 9 varieties and 24 breeding lines) and 35 foreign varieties and lines. Susceptible variety 'Fontana' and resistant variety 'Fredrickson' were used as checks (Buerstmayr et al., 2004). 2. Recombinant inbred line (RIL) population from cross between susceptible variety 'Fontana' and resistant breeding line of North American origin ND 16461 (hereinafter referred to as "RIL population"), created with the purpose of performing quantitative trait locus (QTL) mapping. Lines were in $\mathrm{F}_{5}$ $\mathrm{F}_{7}$ generations during the experiment. 3. Breeding lines in $\mathrm{F}_{4}-\mathrm{F}_{5}$ generation from cross combination between resistant parent 'Fredrickson' and susceptible parent 'Fontana' (hereinafter referred to as 'Fredrickson'/'Fontana' lines).

Table 1. Number of tested genotypes by cut-spike and field inoculation methods during 2008-2012

\begin{tabular}{cccc}
\hline Group of genotypes & $\begin{array}{c}\text { Year of } \\
\text { testing }\end{array}$ & $\begin{array}{c}\text { Cut- } \\
\text { spike } \\
\text { method }\end{array}$ & $\begin{array}{c}\text { Field } \\
\text { inoculation } \\
\text { method }\end{array}$ \\
\hline Collection & $2008-2009$ & 126 & - \\
& 2010 & 47 & - \\
& 2011 & 20 & 59 \\
Recombinant inbred & 2010 & 38 & 68 \\
\hline 'Fre (RIL) population & $2011-2012$ & - & - \\
'Fredrickson'/'Fontana' & 2010 & 47 & - \\
\hline lines & 2011 & - & 52 \\
\hline
\end{tabular}

Growing conditions. Plants were grown in conventional farming system in location Priekuli (lat. $57^{\circ} 19^{\prime} \mathrm{N}$, long. $25^{\circ} 20^{\prime} \mathrm{E}$ ) using corresponding fertilizer amount to reach $5 \mathrm{t} \mathrm{ha}^{-1}$ grain yield level. Herbicides and insecticides were applied as appropriate. Pre-crop was potato. In 2008 and 2009, the plants were grown in $2.3 \mathrm{~m}^{2}$ plots. During 2010-2012 the plants were grown in one to three-row plots (row length $1 \mathrm{~m}$ ) according to the seed amount available. In 2012, in order to assess the necessity of replicated trial and to compare the effect of microenvironment in small row-plots and in-between a larger plot part of collection, 21 varieties were tested in three replications: two replications in three-row plots (46 varieties together were tested in two replications), and one replication was made in the centre of $3.7 \mathrm{~m}^{2}$ plots (inoculated area $0.30 \times 1 \mathrm{~m}$ ).

Meteorological conditions. The average outdoor air temperature during the inoculation was $15.2^{\circ} \mathrm{C}(2008)$, $16.4^{\circ} \mathrm{C}(2009), 20.1^{\circ} \mathrm{C}(2010), 19.3^{\circ} \mathrm{C}(2011)$, and $17.6^{\circ} \mathrm{C}$ (2012). The average maximal daily temperature during the inoculation was $24.2^{\circ} \mathrm{C}(2008), 27.0^{\circ} \mathrm{C}(2009), 22.9^{\circ} \mathrm{C}$ (2010), $25.6^{\circ} \mathrm{C}(2011)$, and $26.8^{\circ} \mathrm{C}$ (2012) (Fig. 1).

The amount of precipitation and air humidity in the years of field inoculations are shown in Figures 2 and 3. Time period from inoculating first genotypes till assessment of disease severity for the latest inoculated genotypes was 10 days for 2008-2010 and 40 days for 2011-2012.

Material used for inoculation. During 20082010 the suspension of conidia was made from dry grains infected by Fusarium culmorum (W.G.Smith) Saccardo (produced by Prophyta GmbH, Germany). Five grams of infection material was incubated in 11 of room temperature water for one hour and then filtered. The final spore concentration for inoculation was $1 \times$ $10^{5}$ conidiospores per 1 . Starting from 2011 because of availability of locally obtained infection material single- 


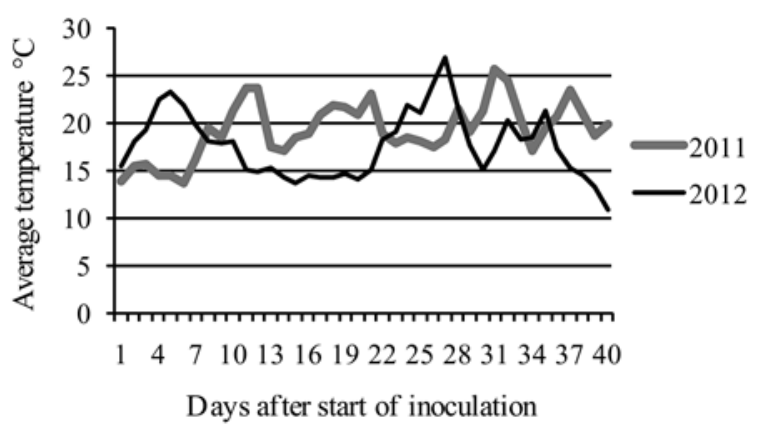

Figure 1. Average air temperatures $\left({ }^{\circ} \mathrm{C}\right)$ in a period of field inoculation (2011 and 2012)

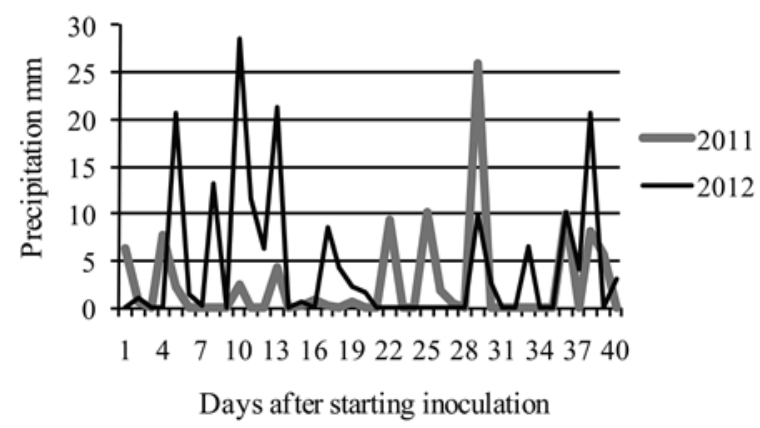

Figure 2. The amount of precipitation $(\mathrm{mm})$ in a period of field inoculation (2011 and 2012)

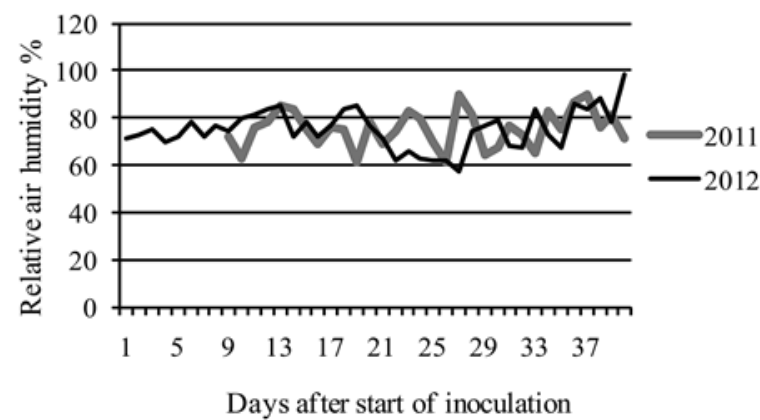

Figure 3. Relative air humidity (\%) in a period of field inoculation (2011 and 2012, data recorded in July and August)

spore isolate of Fusarium culmorum strain Nr. 52 (27-2) from Vilani district (Latvia), was used for inoculation. F. culmorum was grown on agar media for two weeks; mycelium was dissolved in distillate water to make macro conidia suspension with a desired concentration. Macro conidia suspension with concentration $5 \times 104$ spores $\mathrm{ml}^{-1}$ water was applied in 2011. In order to achieve higher disease severity the spore concentration was increased to $7 \times 104$ spores $\mathrm{ml}^{-1}$ in 2012 .

Testing methods. In order to assess resistance to FHB two methods were applied: cut-spike inoculation adapted from Takeda (2004) during 2008-2010 and artificial inoculation in field conditions adapted from Buerstmayr et al. (2002) in 2011 and 2012. Part of the material was tested in parallel with the two methods in 2011 and 2012 (Table 1).

Cut-spike method. Three spikes per genotype were collected at anthesis (growth stage 65 according to decimal code of growth stages of cereals); each spike was assumed as one replication. Spikes were detached from the plants at the second internode from the top, labelled and put in containers of water inside closed humidity chamber made of plastic, which was situated in a glasshouse with an air humidifier (model intended for domestic use). The air humidifier was filled with water twice a day and kept working for $5 \mathrm{~h}$ after filling. The inoculation was done by spraying the inoculum on the spikes in the evening when the air temperature decreased. Temperature and light in the chamber was not controlled and depended on the outdoor conditions. To measure FHB severity the percentage of visibly infected spikelets was scored precisely for each spike according to a linear $0 \%$ to $100 \%$ scale 8 days after inoculation.

Field inoculation method. Every genotype was inoculated individually at its susceptible stage $(50 \%$ of spikes in anthesis) and inoculation was repeated after three days. Inoculation was performed in late afternoon, when air temperature was below $20^{\circ} \mathrm{C}$; it was started on $21^{\text {st }}$ June in 2011 and on $3^{\text {rd }}$ July in 2012. Mist irrigation was not applied and air humidity and temperature depended on the weather conditions. The percentage of spikelets with FHB symptoms was visually estimated three times at days 22 , 24 and 26 after inoculation on a whole plot basis. The area under the disease progress curve (AUDPC) was calculated for each plot and used as the measure of disease severity as described by Buerstmayr et al. (2000).

Mycotoxin analysis. Mycotoxin deoxynivalenol (DON) content was tested in grains from inoculated plots with different levels of disease symptoms from field inoculation trials using AgraQuant ELISA (enzyme linked immunosorbent assay) method. In 2011, 10 samples and in 2012, 21 samples were examined including two samples of variety 'Rubiola' from conventional and organic crop management system without artificial inoculation for control each year.

Statistical analysis. Two-factor ANOVA with replications (year assumed as replication in the case of field inoculation method) and without replications was used for statistical analysis. Phenotypic correlation coefficients were calculated. Broad sense heritability was estimated from the variance components of two-factor ANOVA with replications using formula:

$$
\mathrm{h}^{2}=100 \mathrm{~V}_{\mathrm{g}} /\left(\mathrm{V}_{\mathrm{g}}+\mathrm{V}_{\mathrm{gs}} / \mathrm{s}+\mathrm{V}_{\mathrm{e}} / \mathrm{sr}\right)
$$

where $\mathrm{V}_{\mathrm{g}}$ is genotypic variance, $\mathrm{V}_{\mathrm{gs}}$ - variance of genotype $\times$ year (cut-spike method) / scoring time (field method) interaction, $\mathrm{V}_{\mathrm{e}}$ - error variance, $\mathrm{s}$ - number of years (cut-spike method) or number of scorings (field method), $r$ - number of replications (years for field inoculation method).

\section{Results and discussion}

Cut-spike method. Significant differences between genotypes in amount of spikelets infected by FHB by the cut-spike method were observed. Analysis of variance confirmed that genotype had a significant effect on FHB severity if data for larger amount of genotypes were analysed in two years, as well as for four-year dataset (Table 2). Comparatively larger part of variation for FHB severity was explained by genotype than by the specific testing conditions of the particular year. However, the interaction between both factors was significant and composed about one fourth of variation. The proportion of genotype effect increased to $42 \%$ if analysis of variance was performed for the same 18 genotypes excluding data of the year 2012; the influence proportion of the year and interaction was lower if compared to four-year results. FHB severity of some genotypes (e.g., for varieties 'Kristaps', 'Steffi' and 'Rubiola') was contradictory between the testing years (Table 6). There was a significant, though low 
correlation of FHB severity between the material tested in years 2008 and 2009; correlation coefficients between individual years for the data-set tested in four-year period were ranging from $0.49(p<0.05)$ to $0.63(p<0.01)$ with the exception of non-significant correlation between data in 2008 and 2012.

If compare the average infection levels and ranges of the collection genotypes among the years, noticeably lower values were in 2012 and higher in 2010 (Table 6). The ranges were similar $(0-96.7 \%$ and $2.7-96.7 \%$, respectively) and the average values close (24.3 and 38.5, respectively) in 2008 and 2009, therefore average data for both years are shown. The strain of Fusarium culmorum, used for preparation of inoculum, differed between 2012 and other years; it might be a reason for different infection level in 2012 and lower correlation as well.

Table 2. Significance of factors, partitioning of sum of squares $\left(\eta^{2}\right)$, heritability $\left(h^{2}\right)$ and correlations for Fusarium head blight intensity assessed by cut-spike method during 2008-2010 and 2012

\begin{tabular}{|c|c|c|c|c|}
\hline \multirow{2}{*}{$\begin{array}{l}\text { Source of variation, } \\
\text { statistical parameter }\end{array}$} & \multicolumn{2}{|c|}{$2008-2009$} & \multicolumn{2}{|c|}{$2008-2010$ and 2012} \\
\hline & $p$-value & $\eta^{2} \%$ & $p$-value & $\eta^{2} \%$ \\
\hline $\mathrm{n}$ & \multicolumn{2}{|c|}{126} & \multicolumn{2}{|c|}{18} \\
\hline Genotype & $<0.001$ & 41.6 & $<0.001$ & 33.3 \\
\hline Year & $<0.001$ & 11.9 & $<0.001$ & 21.6 \\
\hline Interaction & $<0.001$ & 24.5 & $<0.001$ & 28.7 \\
\hline $\mathrm{h}^{2} \%$ & \multirow{2}{*}{\multicolumn{2}{|c|}{$\begin{array}{c}41.0 \\
027 * * a\end{array}$}} & \multirow{2}{*}{\multicolumn{2}{|c|}{$\begin{array}{c}71.3 \\
0.59^{* * \mathrm{~b}}\end{array}$}} \\
\hline Correlation coefficient & & & & \\
\hline
\end{tabular}

a - between data in 2008 and $2009,{ }^{\mathrm{b}}$ - between average data in 2008-2010 and data in 2012; ${ }^{* *}-p<0.01$

Fieldinoculation method. Usingfieldinoculation method significant differences between genotypes in FHB severity were observed. Effect of genotype as a factor was significant in all cases and partitioning of sum of squares differed between the groups of genotypes (Table 3). Two years' data showed that genotype had a significant effect on FHB severity. Collection genotypes showed higher effect of genotype than RIL population; it can be explained by higher variation in resistance among the genotypes in collection (coefficients of variation were $30.7 \%$ for RIL population and $66.9 \%$ for collection). Similarly the heritability estimate was higher for the collection genotypes if compared to the RIL population lines. To compare the proportion of effect of the factors genotype and time of scoring on FHB severity, greater part of variation was explained by genotype with the exception of RIL population lines; the interaction between both factors was not significant. Noticeably larger part of FHB severity was explained by genotype than by specific conditions of each year; however, the effect of year was significant except in the case when data of RIL population was processed separately. There was a significant correlation between FHB severity in both years of testing. RIL population showed significant though lower correlation of FHB severity between the years; correlation coefficient between the collection genotypes was comparatively higher, which is in agreement with Buerstmayr et al. (2004), who obtained high correlation $(r=0.72, p<0.0001)$ for 143 various barley genotypes across two years.
Among the genotypes with infection severity significantly below the average level according to the results obtained by field inoculation method during 20112012 were resistance sources mentioned in several studies: 'Russian 6' (average FHB intensity 4.3\%), 'Fredrickson' (5.5\%) and 'Harbin' (5.5\%) (Rudd et al., 2001; Buerstmayr et al., 2004; Takeda, 2004; Hori et al., 2005; 2006; Sato et al., 2008) as well as 'Dneprovskiy' $(1.8 \%)$ provided as resistant by VIR (N. I. Vavilov Research Institute of Plant Industry) indicating that our results can be comparable with those obtained in trials elsewhere (data not shown). The susceptible check 'Fontana' significantly surpassed the average infection level by $21.3 \%$ (Table 6 ). The correlation between AUDPC value and scoring in $26^{\text {th }}$ day after inoculation was high and significant $(r=0.90$, $p<0.01$ ) supporting the conclusion of Buerstmayr et al. (2004) that single scoring is almost as informative as repeated scorings, which can be an important aspect in low-budget breeding program.

In order to assess the importance of replications and the disposition of inoculated plants (in separate rows or in-between a larger plot) for breeding trials part of collection material in 2012 was tested in two replications in rows and in additional replication in-between a plot. Correlation analysis between the intensity of infection showed close correlations between the values in the replicated rows $(r=0.89, p<0.01)$, as well as between the average of rows and the value in-between the plot $(r=0.89, p<0.01)$. Analysis of variance did not show significant differences between replicates in rows, but the

Table 3. Correlations, significance of factors, partitioning of sum of squares $\left(\eta^{2}\right)$ and heritability $\left(h^{2}\right)$ for Fusarium head blight intensity assessed by field inoculation method (2011-2012)

\begin{tabular}{|c|c|c|c|c|c|c|}
\hline \multirow{2}{*}{$\begin{array}{l}\text { Statistical parameter, } \\
\text { source of variation }\end{array}$} & \multicolumn{2}{|c|}{$\begin{array}{l}\text { Recombinant inbred line } \\
\text { (RIL) population }\end{array}$} & \multicolumn{2}{|c|}{ Collection } & \multicolumn{2}{|c|}{ All tested material } \\
\hline & $p$-value & $\eta^{2} \%$ & $p$-value & $\eta^{2} \%$ & $p$-value & $\eta^{2} \%$ \\
\hline $\mathrm{n}$ & \multicolumn{2}{|c|}{96} & \multicolumn{2}{|c|}{52} & \multicolumn{2}{|c|}{150} \\
\hline Correlation coefficient (2011-2012) & \multicolumn{2}{|c|}{$0.33 * *$} & \multicolumn{2}{|c|}{$0.65^{* *}$} & \multicolumn{2}{|c|}{$0.48^{* *}$} \\
\hline \multicolumn{7}{|c|}{ 2-factor $A N O V A$ with replications } \\
\hline Genotype & $<0.001$ & 29.3 & $<0.001$ & 56.5 & $<0.001$ & 41.8 \\
\hline Time of scoring ${ }^{\mathrm{a}}$ & $<0.001$ & 39.2 & $<0.001$ & 10.8 & $<0.001$ & 25.9 \\
\hline Interaction & n.s. ${ }^{b}$ & 7.1 & n.s. & 6.9 & n.s. & 7.6 \\
\hline $\mathrm{h}^{2} \%$ & \multicolumn{2}{|c|}{88.0} & \multicolumn{2}{|c|}{93.9} & \multicolumn{2}{|c|}{90.9} \\
\hline \multicolumn{7}{|c|}{ 2-factor $A N O V A$ without replications } \\
\hline Genotype & $<0.01$ & 66.2 & $<0.001$ & 76.2 & $<0.001$ & 72.6 \\
\hline Year & n.s. & 0.2 & $<0.001$ & 5.3 & $<0.01$ & 1.5 \\
\hline
\end{tabular}

a $-22,24$ and 26 days after inoculation, ${ }^{\mathrm{b}}-$ not significant, $p>0.05$; ${ }^{* *}-$ significant with $p<0.01$ 
replicate in the middle of plot had significantly higher rate of infection $(p<0.01)$, although the difference was comparatively small (average $13.9 \%$ for a separate rows, and $16.8 \%$ in-between the plot). This difference can be explained by the micro-environment: higher humidity because of less accessibility by wind in the plot compared to the separate rows (Brennan et al., 2005). On the basis of mentioned results it follows that evaluation of breeding lines can be carried out both in rows and in-between plots; however, higher rate of infection can be achieved by performing test inside larger plots. If the resources are limited, preliminary screening of breeding material can be done without replications.

DON mycotoxin content. As accumulation of mycotoxins is more relevant than FHB infection severity and the analysis is expensive, DON was determined in selected grain samples in order to check toxin-producing activity of the FHB strain used and the relation of toxin content with the disease scores. The artificially inoculated samples tested for DON content in 2011 showed higher mycotoxin content than the value in European Commission Regulation (EC) No. 1881/2006 (Anonymous, 2006), regardless of infection intensity (Fig. 4). The highest concentration of DON found in the samples examined was 23 times higher than the recommendations, whereas samples of variety 'Rubiola' with natural infection had less than half of the recommended content of the mycotoxin and it was similar in conventionally and organically grown grain. Although the relatively cold and wet weather conditions before grain harvest in 2012 according to Bernhoft et al. (2012) were favourable for production of mycotoxins, detectable DON contamination $\left(255 \mu \mathrm{g} \mathrm{kg}^{-1}\right)$ was found in only one of the tested 21 samples, which is difficult to explain. The average air temperature in the ten day period before harvesting was $17.4^{\circ} \mathrm{C}$ in 2011 and $14.9^{\circ} \mathrm{C}$ in 2012. There should be other factors present in 2012 not allowing the fungus to produce the toxin.

Correlation analysis showed significant and high correlation $(r=0.71, p<0.05)$ between the content of mycotoxin DON in grain and FHB severity in 2011. Similar results have been reported in other studies (Buerstmayr et al., 2004). Because of this high correlation between visual assessment of disease severity and mycotoxin content in grain we can assume that artificial inoculation method in the field with visual FHB intensity assessment can be applicable for both screening for resistance to FHB and mycotoxin accumulation in grain.

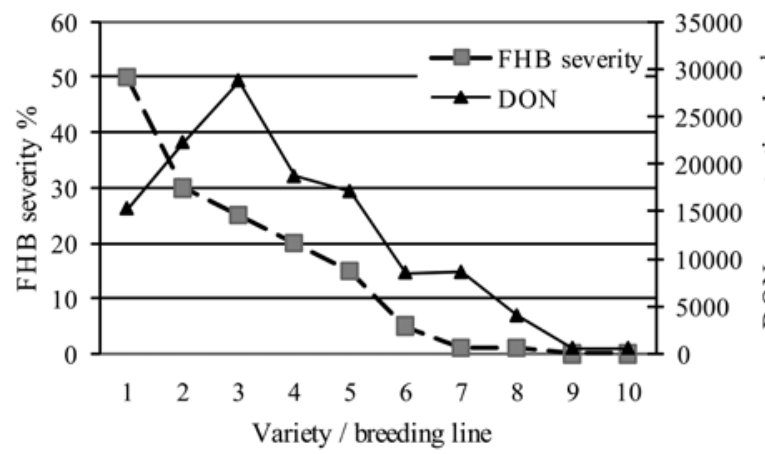

4 - 'Fontana', 5 - 'Rubiola', 7 - 'Fredrickson', 9 - 'Rubiola' (conventional field, natural infection), 10 - Rubiola' (organic field, natural infection), 1, 2, 3, 6 and 8 - breeding lines

Figure 4. Fusarium head blight severity (\%) and mycotoxin content in grain of artificially infected varieties and breeding lines (2011)
Comparison of cut-spike and field inoculation methods. The cut-spike method was adapted as first for FHB resistance screening in our low-budget barley breeding program because it is less laborious in comparison to field methods and more convenient in the case if air humidity and other environmental factors after inoculation in natural conditions are not favourable for development of FHB. However, considering the published findings that the relationships between results in field and greenhouse conditions might be weak (Steffenson, 2003) we decided to compare both methods and choose the most appropriate one. Five-year data showed significant differences between the results obtained by cut-spike and field inoculation methods used for testing FHB severity in different plant material.

The method had a significant effect on FHB severity data with one exception (Table 4). This effect was caused by noticeably higher overall infection level obtained by cut-spike method in comparison to field method because of more favourable conditions (mostly air humidity) for disease development. Genotype as a factor was not significant except the case when testing was done simultaneously with both methods in the year 2012. This can be explained by different reaction of the genotypes to inoculation with FHB done in controlled and in field conditions and in some extent also by differences in climatic conditions between the years and by different inoculation material used in periods of 2008-2010 and 2011-2012. However, aggressiveness of strain used for inoculation should affect all genotypes in a similar way because no significant interaction between varieties and Fusarium strains was reported (Takeda, 2004; Šip et al., 2011). Correlation coefficients indicated significant relationships between the results obtained by both methods in the same year and when the same inoculation material was used (in 2011 and 2012) and also in two cases between results obtained in different years and with different inoculation material (Table 4). Consequently, there is a possibility that results obtained by both methods can give the breeder information of equal meaning only in the case if the meteorological conditions and inoculation material are the same but we cannot state it convincingly because of lack of significant genotype effect in 2011 and fairly low correlation coefficient values. Han and Kim (2005) made a comparison of cut-spike and pot-plant FHB severity screening methods and found that the results obtained by both methods highly correlated and recognised cut-spike method as useful; however, both methods were applied under controlled conditions and the authors give no information on relationships with field conditions. The heritability estimates (Tables 2 and 3 ) were higher for the field inoculation method suggesting that selection can be more effective using this method.

Infection rate assessed by both methods revealed significant differences between the lines of RIL population (Table 5). The correlation between values obtained by cut-spike and field inoculation methods was not significant. Visual estimates of FHB intensity of RIL population in the field 26 days after inoculation did not differ significantly between the years 2011 and 2012 . Distribution of lines according to the infection intensity differed between the methods; the range was wider for cut-spike method, but the trend that most of the lines were with values close to average was similar for both methods (Fig. 5). There were differences in infection intensity between the testing methods.

Similarly to other material, FHB severity assessments of 'Fredrickson'/'Fontana' lines by both 
Table 4. Significance of factors, partitioning of sum of squares $\left(\eta^{2}\right)$ and coefficients of correlation $(r)$ for Fusarium head blight severity data of genotypes obtained by cut-spike and field inoculation methods in different testing years

\begin{tabular}{|c|c|c|c|c|c|c|c|}
\hline \multicolumn{2}{|c|}{ Years of testing } & \multirow{2}{*}{$\mathrm{n}$} & \multicolumn{2}{|c|}{$p$-value } & \multicolumn{2}{|c|}{$\eta^{2} \%$} & \multirow{2}{*}{$r$} \\
\hline Cut-spike method & Field method & & genotype & method & genotype & method & \\
\hline 2008 & 2011 & 27 & n.s. ${ }^{a}$ & 0.002 & 49 & 16 & 0.32 \\
\hline 2008 & 2012 & 22 & n.s. & 0.028 & 52 & 10 & 0.36 \\
\hline 2009 & 2011 & 27 & n.s. & $<0.001$ & 52 & 18 & $0.41 *$ \\
\hline 2009 & 2012 & 22 & n.s. & 0.01 & 52 & 14 & 0.33 \\
\hline 2010 & 2011 & 154 & n.s. & $<0.001$ & 22 & 58 & 0.11 \\
\hline 2010 & 2012 & 107 & n.s. & $<0.001$ & 17 & 70 & $0.19^{*}$ \\
\hline 2011 & 2011 & 30 & n.s. & $<0.001$ & 39 & 37 & $0.47 * *$ \\
\hline 2011 & 2012 & 14 & n.s. & n.s. & 34 & 9 & 0.39 \\
\hline 2012 & 2011 & 40 & n.s. & 0.01 & 51 & 7 & 0.1 \\
\hline 2012 & 2012 & 38 & 0.016 & 0.002 & 61 & 9 & $0.36^{*}$ \\
\hline
\end{tabular}

a - not significant, $p<0.05 ; *$ - significant with $p<0.05, * *$ - significant with $p<0.01$

Table 5. Minimal, maximal and average Fusarium head blight severity (\%) of recombinant inbred line (RIL) population $(\mathrm{n}=96)$ and parent varieties $(2010-2012)$

\begin{tabular}{cccccc}
\hline $\begin{array}{c}\text { Year, } \\
\text { method }\end{array}$ & Genotype & Minimal value & Maximal value & Average & LSD $_{0.05}$ \\
\hline $\begin{array}{c}2010, \\
\text { cut-spike method }\end{array}$ & RIL population & 13.6 & 89.6 & 55.6 & 17.47 \\
\hline 2011-2012 average, & 'Fontana' & 17.5 & 22.5 & 19.2 & 8.8 \\
ND 16461 & 6.0 & 8.5 & 14.5 & \\
\hline
\end{tabular}

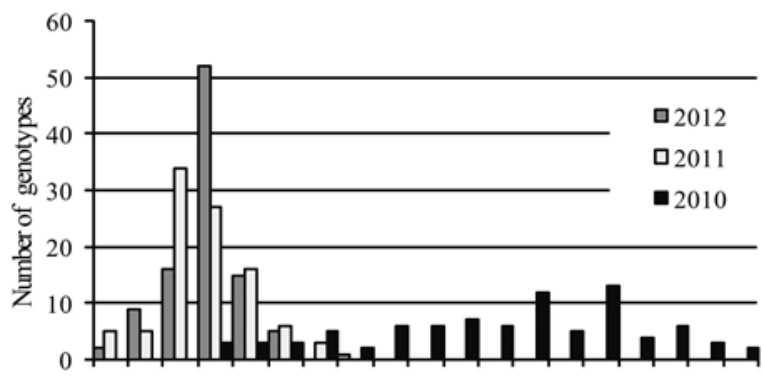

571015202530354045505560657075808590 Intensity of infection \%

Figure 5. Fusarium head blight infection intensity distribution of recombinant inbred line (RIL) population tested by cut-spike (2010) and field inoculation (20112012) methods methods in 2010 and 2011 did not correlate significantly and there was no significant effect of genotype found in analysis of variance.

In several cases the results of particular genotypes obtained by both methods were contradictory (Table 6), e.g., varieties 'Rūja', 'Rasa' and 'Irbe' were among the most resistant genotypes when evaluated by cut-spike method, but their infection intensity was close to average or even significantly higher than average by field inoculation method; for genotypes 1012786-41, 'Peggy' and 'Kombainieris' the opposite trend was demonstrated. However, for the check varieties 'Fredrickson' and 'Fontana' the results obtained by both methods were fairly close and in agreement with those reported by Buerstmayr et al. (2004) and six-row variety 'Dzintars' was among the most susceptible accessions by both methods.

Table 6. Fusarium head blight intensity of collection genotypes evaluated by cut-spike and field inoculation methods during 2008-2012

\begin{tabular}{|c|c|c|c|c|c|c|c|}
\hline \multirow{3}{*}{ Genotype } & \multirow{2}{*}{\multicolumn{4}{|c|}{ Cut-spike method \% }} & \multicolumn{3}{|c|}{ Field inoculation method } \\
\hline & & & & & \multicolumn{2}{|c|}{26 days after inoculation $\%$} & \multirow{2}{*}{$\frac{\text { AUDPC }}{\text { average } 2011-2012}$} \\
\hline & average 2008-2009 & 2010 & 2012 & S.D. ${ }^{4}$ & average $2011-2012$ & S.D. & \\
\hline 1 & 2 & 3 & 4 & 5 & 6 & 7 & 8 \\
\hline 'Kristaps' & $56.7+1$ & 62.0 & 5.0 & 24.7 & $5.3-$ & 0.5 & 26.3 \\
\hline 'Fredrickson' & $8.3-^{2}$ & n.d. ${ }^{3}$ & 11.7 & 5.8 & $5.5-$ & 6.4 & 23.0 \\
\hline 'Balga' & $9.2-$ & 43.3 & 13.3 & 14.9 & $5.8-$ & 1.2 & 30.4 \\
\hline $718676-19$ & 7.2 & 69.3 & $36.7+$ & 25.8 & 7.0 & 2.8 & 32.3 \\
\hline $1273300-50$ & 6.2 & 40.0 & 1.7 & 15.4 & 7.8 & 4.0 & 33.8 \\
\hline $1263098-13$ & $6.2-$ & 47.3 & 3.3 & 18.4 & 8.3 & 4.7 & 34.9 \\
\hline $797877-39$ & 1.3 & 35.3 & 8.3 & 14.0 & 9.5 & 0.7 & 44.8 \\
\hline $1012786-41$ & $77.5+$ & $98.0+$ & $31.7+$ & 25.5 & 10.3 & 0.5 & 39.5 \\
\hline 'Peggy' & $55.8+$ & 64.0 & $43.3+$ & 7.4 & 10.8 & 1.2 & 57.1 \\
\hline 'Kombainieris' & 17.8 & $72.7+$ & 25.0 & 24.1 & 11.7 & 9.4 & 52.5 \\
\hline 'Dziugiai' & $66.7+$ & 64.0 & 15.0 & 25.5 & 11.7 & 2.4 & 53.6 \\
\hline 'Rasa' & $4.5-$ & 44.3 & 6.7 & 17.0 & 11.7 & 2.4 & 66.7 \\
\hline 'Rūja' & $4.8-$ & $35.0-$ & 5.0 & 13.1 & 12.5 & 3.5 & 46.3 \\
\hline 'Steffi' & $65.0+$ & $29.3-$ & 21.7 & 20.8 & 14.2 & 1.2 & 65.4 \\
\hline 'Linga' & $5.3-$ & 62.0 & 10.0 & 24.1 & 15.0 & 0.0 & 85.0 \\
\hline L-2985.1 & $6.5-$ & $33.0-$ & 13.3 & 11.2 & 15.3 & 6.6 & 77.8 \\
\hline 'Rubiola' & $9.5-$ & 70.0 & $0.0-$ & 28.3 & 15.8 & 1.2 & 54.6 \\
\hline 'Heris' & $70.8+$ & 56.3 & 15.0 & 25.0 & 17.5 & 3.5 & 88.3 \\
\hline
\end{tabular}


Table 6 continued

\begin{tabular}{|c|c|c|c|c|c|c|c|}
\hline 1 & 2 & 3 & 4 & 5 & 6 & 7 & 8 \\
\hline 'Justina' & $53.3+$ & 40.7 & 18.3 & 14.5 & 17.5 & 3.5 & 77.5 \\
\hline 'Irbe' & $6.3-$ & $39.0-$ & 8.3 & 13.9 & $20.0+$ & 0.0 & 82.5 \\
\hline 'Fontana' & 37.5 & n.d. & 30.0 & 4.7 & $21.3+$ & 1.8 & 101.3 \\
\hline 'Dzintars' & $81.7+$ & $100+$ & $33.3+$ & 26.9 & $24.2+$ & 27.1 & 97.1 \\
\hline $\mathrm{n}$ & 126.0 & 20.0 & 40.0 & $\mathrm{x}$ & 44.0 & $\mathrm{x}$ & 44.0 \\
\hline Average & 31.4 & 55.3 & 15.6 & $\mathrm{x}$ & 12.9 & $\mathrm{x}$ & 57.8 \\
\hline Min & 1.3 & 29.3 & 0.0 & $\mathrm{x}$ & 2.3 & $\mathrm{x}$ & 7.0 \\
\hline Max & 88.3 & 100.0 & 43.3 & $\mathrm{x}$ & 62.5 & $\mathrm{x}$ & 248.8 \\
\hline $\mathrm{LSD}_{0.05}$ & 17.5 & 16.0 & 15.4 & $\mathrm{x}$ & 6.3 & $\mathrm{x}$ & $\mathrm{x}$ \\
\hline
\end{tabular}

${ }^{1}$ - value significantly above the average of the respective column, ${ }^{2}-$ value significantly below the average of the respective column, ${ }^{3}$ - not determined, ${ }^{4}-$ standard deviation

\section{Conclusions}

1. A significant effect of genotype on Fusarium head blight (FHB) severity was found for both cut-spike and field inoculation methods; the correlations between assessments in different years were significant for both methods in most of the cases. Results suggested that differences between breeding material can be assessed by both methods, but broad sense heritability was higher in the case of field inoculation method.

2 . If the results of both methods were compared, the effect of genotype and correlations were not significant, except the case when inoculation was done in the same year. However, the information obtained by both methods was contradictory for a number of genotypes.

3. Considering the results and the fact that field inoculation method can more likely provide results of equal value to those in natural conditions, field inoculation method was recognized as preferable for screening of spring barley breeding material.

4. A significant correlation between visual estimate of disease severity and deoxynivalenol (DON) concentration in grain was found in one of the testing years indicating that FHB severity scores can provide information about mycotoxin accumulation in the grain.

\section{Acknowledgements}

This research was supported by European Social Fundco-financedprojectNo.2009/0218/1DP/1.1.1.2.0/09/ APIA/VIAA/099.

The authors thank the Latvian Plant Protection Research Centre for providing material for inoculation and personally Olga Treikale for advice. We are grateful to Prof. Hermann Buerstmayr for providing resistant plant material and to Dace Piliksere for help with data statistical analysis and language.

Received 30112012

Accepted 22082013

\section{References}

Anonymous. 2006. Commission Recommendation of 17 August 2006 on the presence of deoxynivalenol, zearalenone, ochratoxin A, T-2 and HT-2 and fumonisins in products intended for animal feeding (2006/576/EC). Official Journal of the European Union, 229: 7-9

Audenaert K., Van Broeck R., Bekaert B., De Witte F., Heremans B., Messens K., Höfte M., Haesaert G. 2009. Fusarium head blight (FHB) in Flanders: population diversity, inter-species associations andDON contamination in commercial winter wheat varieties. European Journal of Plant Pathology, 125: 445-458 http://dx.doi.org/10.1007/s10658-009-9494-3

Bernhoft A., Torp M., Clasen P. E., Løes A. K., Kristoffersen A. B. 2012. Influence of agronomic and climatic factors on Fusarium infestation and mycotoxin contamination of cereals in Norway. Food Additives and Contaminants. Part A: Chemistry, Analysis, Control, Exposure and Risk Assessment. 29 (7): 1129-1140

http://dx.doi.org/10.1080/19440049.2012.6724736

Brennan J. M., Egan D., Cooke B. M., Doohan F. M. 2005. Effect of temperature on head blight of wheat caused by Fusarium culmorum and F. graminearum. Plant Pathology, 54 (2): $156-160$ http://dx.doi.org/10.1111/j.1365-3059.2005.01157.x

Browne R. A., Cooke B. M. 2005. A comparative assessment of potential components of partial disease resistance to Fusarium head blight using a detached leaf assay of wheat, barley and oats. European Journal of Plant Pathology. 112: 247-258 http://dx.doi.org/10.1007/s10658-005-2077-z

Buerstmayr H., Steiner B., Lemmens M., Ruckenbauer P. 2000. Resistance to Fusarium head blight in winter wheat heritability and trait associations. Crop Science. 40: 10121018 http://dx.doi.org/10.2135/cropsci2000.4041012x

Buerstmayr H., Lemmens M., Hartl L., Doldi L., Steiner B., Stierschneider M., Ruckenbauer P. 2002. Molecular mapping of QTLs for Fusarium head blight resistance in spring wheat. I. Resistance to fungal spread (type II resistance). Theoretical and Applied Genetics, 104: 84-91 http://dx.doi.org/10.1007/s001220200009

Buerstmayr H., Legzdina L., Steiner B., Lemmens M. 2004. Variation for resistance to Fusarium head blight in spring barlev. Euphvtica. 137: 279-290 http://dx.doi.org/10.1023/B:EUPH.0000040440.99352.b9

Diamond H., Cooke B. M. 1999. Towards the development of a novel in vitro strategy for early screening of fusarium ear blight resistance in adult winter wheat plants. European Journal of Plant Pathologv. 105: 363-372 http://dx.doi.org/10.1023/A:1008717602202

Doohan F. M., Brennan J., Cooke B. M. 2003. Influence of climatic factors on Fusarium species pathogenic to cereals. European Journal of Plant Pathology. 109: 755-768 http://dx.doi.org/10.1023/A:1026090626994

Grewal T. S., Rossnagel B. G., Arganosa G., Savard M., Scoles G. J. 2004. Greenhouse screening and NIRS for Fusarium head blight in barley. $9^{\text {th }}$ International Barley Genetics Symposium. Brno, Czech Republic, p. 781-786

Han O.-K., Kim J.-G. 2005. Establishment of artificial screening methods and evaluation of barley germplasms for resistance to Fusarium head blight. Korean Journal of Crop Science, 50 (3): 191-196

Hori K., Kobayashi T., Sato K., Takeda K. E. 2005. QTL analysis of Fusarium head blight resistance using a highdensity linkage map in barley. Theoretical and Applied Genetics. 111: 1661-1672 http://dx.doi.org/10.1007/ s00122-005-0102-4

Hori K., Sato K., Kobayashi T., Takeda K. 2006. QTL analysis of Fusarium head blight severity in recombinant inbred population derived from a cross between two-rowed barley varieties. Breeding Science. 56: 25-30 http://dx.doi.org/10.1270/jsbbs.56.2

Ioos R., Belhadj A., Menez M. 2004. Occurrence and distribution of Microdochium nivale and Fusarium species isolated from barley, durum and soft wheat grains in France from 2000 to 2002. Mycopathology. 158: 351-362 http://dx.doi.org/10.1007/s11046-004-2228-3 
Mesfin A., Smith K. P., Dill-Macky R., Evans C. K., Waugh R., Gustus C. D., Muehlbauer G. J. 2003. Quantitative trait loci for Fusarium head blight resistance in barley detected in a two-rowed by six-rowed population. Crop Science, 43: 307-318 http://dx.doi.org/10.2135/cropsci2003.0307

Mesterhazy A. 1995. Types and components of resistance to Fusarium head blight of wheat. Plant Breeding, 114: 377 386 http://dx.doi.org/10.1111/j.1439-0523.1995.tb00816.x

Mesterhazy A., Bartók T., Mirocha C. G., Komoróczy R. 1999. Nature of wheat resistance to Fusarium head blight and the role of deoxynivalenol for breeding. Plant Breeding, 118 (2): $97-110$ http://dx.doi.org/10.1046/j.1439-0523.1999.118002097.x

Parry D. W., Jenkinson P., McLeod L. 1995. Fusarium ear blight (scab) in small grains: a review. Plant Pathology, 44: 207238 http://dx.doi.org/10.1111/j.1365-3059.1995.tb02773.x

Placinta C. M., Mello J. P. F. D, Macdonald A. M. C. 1999. A review of worldwide contamination of cereal grains and animal feed with Fusarium mycotoxins. Animal Feed Science and Technology, 78: 21-37 http://dx.doi.org/10.1016/S0377-8401(98)00278-8

Rudd J. C., Horsley R. D., McKendry A. L., Elias E. M. 2001. Host plant resistance genes for Fusarium head blight: sources, mechanisms, and utility in conventional breeding svstems. Crop Science. 41: 620-627 http://dx.doi.org/10.2135/cropsci2001.413620x

Sato K., Hori K., Takeda K. 2008. Detection of Fusarium head blight resistance QTLs using five populations of top-cross progeny derived from two-row $\times$ two-row crosses in barlev. Molecular Breeding. 22: 517-526 http://dx.doi.org/10.1007/s11032-008-9195-1

Singh R. P., Ma H., Rajaram S. 1995. Genetic analysis of resistance to scab in spring wheat cultivar Frontana. Plant Diseases, 79: 238-240 http://dx.doi.org/10.1094/PD-79-0238

Snijders C. H. A. 1990. Genetic variation for resistance to Fusarium head blight in bread wheat. Euphytica, 50: 171$179 \mathrm{http}: / / \mathrm{dx}$.doi.org/10.1007/BF00023642
Steffenson B. J. 2003. Fusarium head blight of barley: impact, epidemics, management, and strategies for identifying and utilizing genetic resistance. Fusarium head blight of wheat and barley. Leonard K. J., Bushnell W. R. (eds). St. Paul, USA, p. 241-295

Šip V., Chrpova J., Štočkova L. 2011. Evaluation of resistance to Fusarium head blight in wheat using different source of inoculums. Czech Journal of Genetics and Plant Breeding, 47 (4): 131-139

Takeda K. 2004. Inheritance of the head blight resistance in barley. $9^{\text {th }}$ International Barley Genetics Symposium. Brno, Czech Republic, p. 302-307

Xu X.-M., Parry W., Nicholson P., Thomsett M. A., Simpson D., Edwards S. G. 2005. Predominance and association of pathogenic species causing Fusarium ear blight in wheat. European Journal of Plant Pathology, 112: 143-154 http://dx.doi.org/10.1007/s10658-005-2446-7

Yoshida M., Kawada N., Tohnooka T. 2005. Effect of row type, flowering type and several other spike characters on resistance to Fusarium head blight in barley. Euphytica, 141: 217-227 http://dx.doi.org/10.1007/s10681-005-7008-8

Waalwijk C., Kastelein P., de Vries I., Kerényi Z., van der Lee T., Hesselink T. 2003. Major changes in Fusarium spp. in wheat in the Netherlands. European Journal of Plant Pathology, 109: 743-754

http://dx.doi.org/10.1023/A:1026086510156

Zhu H., Gilchrist L., Hayes P., Kleinhofs A., Kudrna D., Liu Z., Prom L., Steffenson B. Toojinda T., Vivar H. 1999. Does function follow form? Principal QTLs for Fusarium head blight (FHB) resistance are coincident with QTLs for inflorescence traits and plant height in a doubled-haploid population of barley. Theoretical and Applied Genetics, 99: 1221-1232 http://dx.doi.org/10.1007/s001220051328

ISSN 1392-3196 / e-ISSN 2335-8947

Zemdirbyste-Agriculture, vol. 100, No. 3 (2013), p. 317-324

DOI 10.13080/z-a.2013.100.041

\title{
Paprastojo vasarinio miežio (Hordeum vulgare L.) atsparumo varpų fuzariozei ịvertinimo metodų palyginimas
}

\author{
G. Ūsele, I. Beinaroviča, I. Mežaka, L. Legzdiņa \\ Latvijos valstybinis Priekulès augalų selekcijos institutas
}

\begin{abstract}
Santrauka
Varpų fuzariozė yra plačiai paplitusi javų, taip pat ir vasarinių miežių liga, galinti padaryti didelių grūdų derliaus nuostolių ir pabloginti grūdų kokybę. Atsparios veislès pasižymi didžiausiu varpų fuzariozès sumažinimo potencialu. Šio tyrimo metu varpų fuzariozei ịvertinti taikyti du metodai, naudojant Fusarium culmorum. Taikyti nupjautų varpų bei užkrato lauko sąlygomis metodai ir naudoti latviškos bei užsienietiškos kilmės vasarinio miežio (Hordeum vulgare L.) genotipai. Taikant nupjautų varpų metodą, 2008-2009 m. tirti 126 genotipai, o $2010 \mathrm{~m}$. 180 genotipu. 2011 ir 2012 m. taikytas užkrato lauko sąlygomis metodas ir atitinkamai 207 bei 164 genotipai; dalis genotipų buvo tiriami abiem metodais. Reikšmingi skirtumai tarp genotipų nustatyti taikant abu metodus $(p<0,001)$, tačiau lauko užkrato metodas parodè didesnę genotipo ịtaką ir didesnị paveldimumą. Abu metodai buvo vienodai veiksmingi naudojant ligos pažeisto ploto kreivę (AUDPC) ir balą, gautą praejjus 26 dienoms po užkrètimo. Koreliacija tarp metodụ skirtingais metais nebuvo esminè, tačiau tụ pačių metų duomenys esmingai koreliavo $(r=0,36-0,47, p<0,05)$. Tyrimų rezultatai rodo, kad selekcinès medžiagos skirtumus galima ịvertinti abiem metodais, tačiau gauta informacija apie daugelị genotipų buvo prieštaringa. Atsižvelgiant ị tai, kad užkrato lauko sąlygomis metodo taikymas davė panašius i gautus natūraliomis sąlygomis rezultatus, užkrato lauko sąlygomis metodas pripažintas tinkamesniu vasarinio miežio selekcinès medžiagos tyrimams. Esminè koreliacija $(r=0,71, p<0,05)$ tarp ligos vizualinio intensyvumo ivertinimo ir mikotoksino deoksinivalenolio (DON) koncentracijos grūduose buvo nustatyta $2011 \mathrm{~m}$., bet $2012 \mathrm{~m}$. dèl nepalankių aplinkos sąlygų DON formavimasis buvo slopinamas.
\end{abstract}

Reikšminiai žodžiai: DON, Fusarium culmorum, genotipo efektas, nupjautų varpų metodas, užkrato lauke metodas. 